\title{
ETIKA KOMUNIKASI PUBLIC RELATIONS DALAM MENJAGA CITRA
}

\author{
PERUSAHAAN \\ Brahmastra Nandiwardhana ${ }^{1}$ \\ Ilmu Komunikasi, Universitas Diponegoro, Semarang, Indonesia \\ Email: brahmastranw08@gmail.com \\ COMMUNICATION ETHICS IN PUBLIC RELATIONS TO MAINTAIN THE IMAGE

\section{OF COMPANY} \\ ABSTRACT
}

\begin{abstract}
Ethics in public relations as the application of knowledge, understanding, and reasoning about "right or wrong" and "good or bad" behavior in the professional practice of public relations. Professional ethics in public relations can carry out their roles for the represented company. Public Relations Professional Ethics are also created so that they can carry out their roles for the company they represent. As a company that relies on public confidence, a positive image into a separate requirement for the airline Lion Air. The Lion Air airline is a commercial airline that is widely used by the public because of its affordable price and has many inter-island travel routes in Indonesia. Companies related to transportation services are certainly in the field to receive a variety of various problems relating to consumers. therefore, a public relations is needed that can manage the problems that exist in the field or social media in order to maintain the good image of the company. The focus of this study is to analyze the communication ethics in public relations for Lion Air airlines in overcoming and resolving the cases in order to maintain the image of the company. A qualitative method with a content analysis approach was used in this study. The result of this study is ethics in public relations used as a guide for the professionals of public relations in their actions, considerations, and decisions. Public relations who carry out the practice of conveying information to the public through media as a company representative certainly every word, expression, and attitude should be done and considered carefully.
\end{abstract}

Keywords: Image, ethics, communication, public relations.

\begin{abstract}
ABSTRAK
Etika Public Relation sebagai penerapan pengetahuan, pemahaman dan penalaran tentang perilaku "benar atau salah" dan "baik atau buruk" dalam praktik profesional Public Relation. Etika Profesional Public Relation juga dibuat agar dapat menjalankan perannya untuk perusahaan yang diwakilinya. Sebagai perusahaan yang mengandalkan pada kepercayaan publik, citra positif menjadi sebuah keharusan tersendiri bagi maskapai Lion Air. Maskapai Lion Air merupakan maskapai komersial yang banyak digunakan masyarakat karena harganya yang terjangkau dan memiliki banyak rute perjalanan antar pulau di Indonesia. Perusahaan yang berkaitan dengan jasa pelayanan transportasi ini tentu di dalam lapangan menerima banyak permasalahan yang bermacam-macam yang berhubungan dengan konsumen. maka dari itu, dibutuhkan seorang public relations yang dapat mengelola permasalahan yang ada di lapangan atau media sosial guna menjaga citra baik perusahaan. Fokus penelitian ini adalah menganalisis etika komunikasi Public Relations maskapai Lion Air dalam mengatasi dan menyelesaikan kasus guna menjaga citra perusahaan. Penelitian ini menggunakan metode kualitatif, dengan pendekatan Analisis Isi. Hasil penelitian ini yaitu Etika Public Relations menjadi pedoman para profesional Public Relations dalam bertindak, bahan pertimbangan, dan membuat keputusan. Public Relations yang melaksanakan praktik menyampaikan informasi kepada publik melalui media sebagai perwakilan perusahaan, tentunya setiap kata-kata, ekspresi, dan sikap harus dilakukan dan dipertimbangkan dengan hatihati.
\end{abstract}

Kata Kunci : Citra, etika, komunikasi, public relations. 


\section{PENDAHULUAN}

Sebagai perusahaan yang mengandalkan pada kepercayaan publik, persoalan citra positif menjadi sebuah keharusan tersendiri bagi maskapai Lion Air. Terkait hal ini etika dalam menyelesaikan masalah di lapangan perlu adanya komunikasi yang baik. Etika sesungguhnya merupakan studi tentang benar atau salah dalam tingkah laku manusia, dan etika pada dasarnya hendak mencari tindakan manakah yang benar atau baik. Ada dua penggolongan etika, yaitu etika umum dan etika khusus. Etika umum berkaitan dengan kondisi dasar bagaimana manusia bertindak etis dalam mengambil keputusan etis dan mengacu pada prinsip moral yang pedoman menilai "baik dan buruknya” suatu tindakan yang dilakukan oleh seseorang atau kelompok. Etika khusus membahas penerapan prinsip-prinsip moral dasar dalam bidang khusus, yaitu bagaimana mengambil keputusan dan bertindak dalam kehidupan sehari-hari para proses dan fungsional dari suatu organisasi atau dapat juga dikatakan sebagai seorang profesional untuk bertindak etis yang berlandaskan teori-teori etika dan prinsipprinsip moral dasar. Etika khusus ini mengangkut bidang profesional yang salah satunya adalah etika komunikasi public relations.

Para filsafat mendefinisikan etika Public Relation sebagai penerapan pengetahuan, pemahaman dan penalaran tentang perilaku "benar atau salah" dan "baik atau buruk" dalam praktik profesional Public Relation (Parsons, 2016). Menurut Kantian (Bowen, 2005) melihat etika pengambilan keputusan adalah dengan melibatkan unsur triangle, yang terdiri dari : duty; intention; dignity; and respect. Pada framework yang diusulkan oleh Kantian, bahwa seorang profesional untuk membuat sebuah keputusan ada kode etiknya. Sementara itu, Etika Profesional Public Relation juga dibuat yang harapannya pada profesional ini dapat menjalankan perannya untuk perusahaan yang diwakilinya. Salah satu praktik Public Relation adalah berhubungan dengan media relations. Public Relation membutuhkan media untuk menyalurkan pesan-pesan kepada publik. Sehingga praktik Public Relation dalam menyampaikan pesan-pesan kepada publiknya harus menyadari beberapa hal sesuai dengan pedoman berperilaku Public Relation terhadap media massa, seperti tidak menggunakan kata-kata yang membuat publik bimbang, salah paham, atau justru menimbulkan polemik lain. Bagi perusahaan, membangun citra yang baik di mata publik merupakan suatu keharusan 
agar perusahaan mampu bertahan dan maju berkembang. Seorang public relations harus berpikir kreatif agar perusahaan tetap terus memiliki citra baik dengan segala macam inovasi yang diberikan. Namun, tidak hanya mencari cara agar citra perusahaan baik tetapi hal yang berat bagi seorang public relations adalah ketika perusahaan mendapatkan masalah, maka public relations harus mengembalikan kondisi perusahaan yang terpandang buruk karena masalah tersebut menjadi baik kembali dan tentunya dalam mengembalikan kondisi tersebut, public relations harus tepat dalam bertindak, bahan pertimbangan, dan membuat keputusan. Belum lagi jika berhadapan dengan media, maka harus ada pemilihan kata-kata, ekspresi dan sikap yang harus dilakukan dan dipertimbangkan dengan hati-hati. Hal tersebut tidak terlepas dari perusahaan-perusahaan di Indonesia. Salah satunya Perusahaan di bidang transportasi udara yang merupakan sebuah bisnis dipandang cukup signifikan meningkat karena banyak masyarakat yang membutuhkan efisiensi waktu ketika berpindah antar kota atau provinsi. Transportasi udara di Indonesia merupakan sarana penting untuk menghubungkan ribuan pulau di nusantara. Pertumbuhan kelas menengah dan tumbuhnya penerbangan bertarif rendah membuat banyak masyarakat menggunakan pesawat sebagai alat transportasi mereka untuk pergi ke antar kota atau antar pulau. Akan tetapi, masalah keselamatan, sistem pelayanan, serta fasilitas setiap maskapai selalu ada kelebihan dan kekurangannya. Lion Air merupakan salah satu maskapai yang besar di indonesia, sebagian masyarakat Indonesia menggunakan maskapai ini karena Lion Air memiliki rute penerbangan domestik yang relatif banyak dibandingkan dengan maskapai lainnya. Selain itu, Lion Air juga menawarkan tarif yang relatif murah. Banyak masyarakat yang menggunakan maskapai Lion Air, tetapi banyak juga masalah pelayanan dan keselamatan yang menimpa Lion Air. Salah satunya pada tanggal 23 april 2019 terjadi masalah pelayanan antara pihak Lion Air dengan penumpang terkait ketentuan kelebihan bagasi.

Mengutip dari laman Kompas.com, sejumlah "enam penumpang ditinggal pesawat karena diduga kelebihan bagasi". Enam penumpang tersebut mengatakan bahwa mereka membawa 4 koper namun petugas mendapatkan laporan bahwa enam penumpang tersebut membawa sembilan koper. Dari laporan tersebut akhirnya muncul perdebatan antara petugas bandara dengan penumpang yang membuat enam penumpang tersebut harus tertinggal pesawat (Ramdhani, 2019). Dari laman detiknews.com, menjelaskan cerita dan video penumpang yang memprotes soal bagasi kabin Lion Air viral di media sosial. Peristiwa 
yang dialami oleh Esa Sinaga Mesha dan keluarganya saat hendak terbang dari Bandara Husein Sastranegara ke Bandara kualanamu pada 23 April 2019. Mesha sempat menyiarkan kejadian itu lewat live Facebook. Seluruh keluarganya dihentikan oleh petugas bandara karena dianggap kelebihan membawa barang bagasi. Dari penjelasan penumpang, petugas bandara juga menyuruh penumpang untuk membawa barangnya masing-masing, satu orang satu barang. Padahal dari enam penumpang itu salah satunya anak balita berumur 3,5 tahun. Akibat persoalan itu terjadi perdebatan yang pada akhirnya enam penumpang tersebut ketinggalan pesawat, sehingga terpaksa membeli tiket baru tanpa kompensasi pihak maskapai (Kami \& Dinillah, 2019).

Mengutip dari laman detik.com menjelaskan, Corporate Communications Strategic of Lion Air Danang Mandala Prihantoro mengatakan, saat proses check-in, penumpang melaporkan tiga bagasi total $30 \mathrm{~kg}$ dan empat bagasi kabin. Petugas layanan darat (ground handling) memberikan tanda label kuning (baggage tag) pada keempat barang tersebut. Petugas ground handling lalu melihat bagasi kabin yang dibawa penumpang tersebut ternyata ada sembilan. Petugas lalu mengatakan jumlah itu melebihi batas. Dalam kejadian ini, pihak Lion Air hanya mencoba menjelaskan awal permasalahan ini muncul dan menjelaskan bagaimana ketentuan batas maksimum bagasi maskapai tetapi tidak memberikan solusi untuk untuk kasus tersebut. Perilaku yang dilakukan Danang menurut penumpang tidak ada solusi dan rasa empati dalam melayani penumpang, terlebih setelah penumpang mengalah untuk membeli tiket baru, permintaan maaf dari petugas juga tidak ada (Kami \& Dinillah, 2019).

Atas sikap dari pihak Lion Air, dapat menyebabkan turunya reputasi kinerja dan mengubah persepsi serta citra baik perusahaan dalam pelayanan. Terlebih, hal tersebut dapat mempengaruhi pada tingkat kepercayaan masyarakat kepada kinerja maskapai Lion Air. Menurut Effendy dalam (Ruslan, 2013) peran utama Public Relation sebagai (1) communicator atau penghubung antara organisasi atau lembaga yang diwakili dengan publiknya, (2) membina relationship, yaitu berupaya membina hubungan yang positif dan saling menguntungkan dengan pihak publiknya, (3) peranan back up management, yakni sebagai pendukung dalam fungsi manajemen organisasi atau perusahaan, (4) membentuk corporate image, artinya peran public relation berupaya menciptakan citra bagi organisasi atau perusahaan. Namun, dalam kasus Lion Air tidak menerapkan hal itu yang membuat 
masyarakat memandang maskapai Lion Air tidak bertanggung jawab dan tidak memiliki etika dalam menyelesaikan masalah. Oleh karena itu, pada penelitian ini akan diulas mengenai Kode Etik Public Relation, Etika Media Relation dan tanggung jawab Public relation sebagai seseorang yang dipercaya untuk mewakili perusahaannya dalam meningkatkan serta menjaga citra perusahaan.

\section{METODE PENELITIAN}

Penelitian ini dilakukan dengan metode penelitian kualitatif dengan mengkaji pemberitaan di media online. Penelitian kualitatif dipengaruhi oleh naturalistik-interpretif (Creswell, 1994). Penelitian ini memperhatikan proses dan peristiwa pada pemberitaan online. Model pendekatan penelitian yang dipakai adalah analisis isi (content analysis). Analisis dilakukan terhadap isi beberapa media online sebagai sumber data utama.

Dalam penelitian ini, teknik pengumpulan data berupa pemberitaan media online dengan mengambil satu kasus utama dan kemudian melihat kasus sebelum dan sesudah kasus utama.

Media yang dijadikan fokus analisis adalah media online yang melakukan pemberitaan terkait klarifikasi dari pihak perusahaan dalam menghadapi masalah. Peneliti mengumpulkan 3 pemberitaan di media online diantaranya merupakan pemberitaan utama sedangkan dua lainnya merupakan pemberitaan yang di analisis untuk melihat perbandingan kinerja public relation dalam menyelesaikan masalah yang viral di media. Dari ketiga pemberitaan, yang akan di analisis yaitu bagaimana pihak perusahaan memberikan penjelasan di media terkait permasalahan yang muncul di publik. Dari situ akan di analisis kinerja public relation dalam menangi masalah di publik.

\section{HASIL DAN PEMBAHASAN}

Peneliti mengumpulkan tiga kasus yang menimpa perusahaan Lion Air sepanjang bulan februari hingga april tahun 2019. Kasus utamanya yang ada di publik dan sempat viral karena pihak yang merasa dirugikan ketika insiden itu melakukan Live Facebook yaitu tentang ketentuan kapasitas bagasi dan petugas menyuruh anak balita membawa barangnya bawaanya sendiri, kejadian itu terjadi pada tanggal 23 april 2019. Dalam video tersebut digambarkan bahwa petugas mempermasalahkan koper atau barang yang di bawa enam penumpang bahwa barangnya melebihi kapasitas dan petugas menghendaki satu orang 
membawa satu barang, namun salah satu penumpang tersebut merupakan anak balita yang berumur 3,5 tahun. Pihak Lion Air melalui Danang sebagai Corporate Communications Strategic of Lion Air mencoba menjelaskan pada media bagaimana ketentuan kapasitas bagasi pesawat yang berlaku. Danang juga mengklarifikasi bahwa petugas dilapangan tidak mengatakan dan menyuruh anak balita membawa barang bawaanya sendiri. Sayangnya dalam penyelesaian masalah itu pihak Lion Air tidak memberikan win win solution, bahkan permintaan maaf. Atas kejadian tersebut penumpang sampai harus membeli tiket pesawat lagi karena ditinggal oleh (Ramdhani, 2019).

Pemberitaan pada bulan sebelumnya dengan kasus yang berbeda yaitu "ditemukan binatang yang diduga kalajenging pada salah satu bagasi kabin penumpang" kejadian ini terjadi pada tanggal 15 februari 2019. Bermula setelah mendarat di bandara Internasional Soekarno-Hatta, salah satu penumpang melihat serupa binatang kalajengking di bagasi kabin. Penumpang sempat mangambil gambar dan membagikan gambar tersebut di media sosial. Menanggapi hal tersebut, Danang sebagai Corporate Communications Strategic of Lion Air menjelaskan bahwa disaat itu juga langsung melakukan pengecekan kembali namun tidak ditemukan binatang yang dimaksud. Danang juga menyampaikan bahwa di hari sebelumnya sudah dilakukan pengecekan lebih awal (pre-flight check) dan dinyatakan siap terbang (save to flight). Tetapi permasalahan disini adalah bahwa salah satu penumpang melihat dan memviral kan kejadian itu di media sosial, namun pihak Lion Air tidak meminta maaf kepada publik atas apa yang terjadi dilapangan (Tanjung, 2019).

Terakhir merupakan kasus salah satu pilot Lion Air memukul pegawai hotel di surabaya. Kejadian tersebut terekam CCTV hotel serta di unggah di media sosial facebook dan lewat salah satu akun video tersebut sudah dibagikan sebanyak 26.000 kali dan mendapatkan 10.000 komentar. Dalam rekaman itu, tertera kejadian pada tanggal 30 April 2019. Saat salah satu media menghubungi Corporate Communications Strategic Lion Air, Danang Mandala Prihantoro mengatakan, pihaknya telah memberi sanksi terhadap pilot tersebut yaitu dengan tidak menugaskan menjadi pilot. Pihak Lion Air juga mengatakan, akan memproses lebih lanjut dengan mengumpulkan data, informasi dan keterangan lain agars jika terbukti salah maka akan diberi sanksi tegas dengan memperhentikan dari perusahaan. Namun dari pernyataan tersebut hingga selesai akhir tahun, pihak Lion Air tidak memberikan keterangan lebih lanjut apakah kejadian tersebut benar atau tidak. Padahal jika memang ada bukti dan pihak Lion Air bisa menunjukan salah atau tidaknya akan membuat media dan 
publik melihat maskapai Lion Air bertanggung jawab tidak hanya pada pihak hotel tetapi kepercayaan masyarakat atas kinerjanya dalam penyelesaian masalah (Arnani, 2019).

Dari ketiga pemberitaan tersebut dapat dilihat bahwa setiap pemberitaan selalu berhubungan dengan media yang membuat berita itu viral serta bersangkutan dengan customer. Dengan viralnya berita tersebut berarti banyak masyarakat mengetahui dan beranggapan buruk dengan perusahaan itu. Namun pihak Lion Air dari tiga berita itu hanya mengklarifikasi dan lebih banyak mengatakan bahwa pihak Lion Air sudah bekerja sesuai aturan, tidak terlebih dahulu meminta maaf atas kejadian tersebut. Padahal pentingnya memintaa maaf pada publik di media bisa meredakan kekecewaan masyarakat dan perusahaan akan dipandang bertanggung jawab atas kejadian itu. Maka, pentingnya Etika Public Relations guna mengutamakan apa yang terlebih dahulu dilakukan dalam menghadapi masalah. Dalam berbisnis yang berhubungan dengan pelayanan, maka sangat penting konsumen/kostumer adalah yang utama karena bagaimana pun juga dengan kita melayani, mereka akan merasa perusahaan ini peduli untuk menjaga loyalitas.

Kode Etik Public Relation diartikan sebagai kegiatan yang merupakan profesi secara praktis memiliki seni keterampilan atau pelayanan tertentu yang berlandaskan latihan, kemampuan, dan pengetahuan serta diakui sesuai dengan standar etikanya. Setiap profesi tertentu harus mempunyai kode etik sebagai pedoman serta acuan dalam bertindak dan berperilaku melaksanakan peran serta fungsi profesinya masing-masing. Kode etik itu sendiri, sifatnya adalah mengikat, baik secara normatif dan etis, maupun sebagai tanggung jawab dan kewajiban moral sebagai bagian dari anggota profesi, yang menjalankan aktivitas dan tanggung jawabnya di masyarakat. Baker dan Martinson (Lieber, 2005) menawarkan beberapa poin sebagai pertimbangan etis untuk praktisi PR sekarang ini, yang terdiri dari : trustfulness; authenticity; respect; equity; dan social responsibility.

Pemahaman mengenai kode etik penting bagi para profesional Public relations dalam menjalankan aktivitas komunikasi. Karena, peran Public relations disini adalah sebagai representatif perusahaan yang ia wakili, sehingga peran dan fungsinya sangat penting dalam menciptakan brand image bagi dirinya sebagai PR/Humas juga untuk lembaga yang bersangkutan. Kode Etika Profesi, Perhumas Indonesia, 5 yang telah disepakati terkait perilaku terhadap publik dan massa adalah sebagai berikut $(1 ;)$ Seorang anggota hendaknya melakukan kegiatan profesionalnya sejalan dengan kepentingan publik dan dengan penuh 
hormat demi menjaga martabat baik anggota masyarakat (2;) Seorang anggota hendaknya tidak melakukan kegiatan dalam praktik apa pun yang dapat merusak integritas saluran komunikasi massa (3;) Seorang anggota hendaknya tidak menyebarluaskan dengan sengaja informasi palsu dan dapat menyesatkan masyarakat (4;) Seorang anggota hendaknya di setiap waktu berusaha memberikan gambaran seimbang dan terpercaya terhadap kepentingan organisasi yang dilayaninya (5;) Seorang anggota hendaknya tidak membentuk organisasi apa pun untuk tujuan tertentu selain untuk kepentingan pribadi dari pihak kliennya atau pimpinannya. Demikian juga hendaknya tidak memanfaatkan organisasi demi tujuan yang tidak dapat dipertanggungjawabkan demi kepentingan pribadi.

Setiap profesi memiliki kode etik profesi yang mengikat para anggotanya secara etis. Moral dan profesionalisme harus ditaati atau dipatuhi dalam menjalankan aktivitas, peran dan fungsinya. Beberapa PR/Humas memiliki peran yang berbeda, dalam artian menyesuaikan dengan pedoman pada perusahaan tempat bekerja. Namun pada dasarnya profesional Public Relations memiliki fungsi yang sama yaitu, (1;) Bertindak sebagai communicator dalam kegiatan komunikasi pada organisasi perusahaan, prosesnya berlangsung dalam dua arah timbal balik (two way traffic reciprocal communication). Dalam hal ini, satu pihak melakukan fungsi komunikasi merupakan bentuk penyebaran informasi, di lain pihak komunikasi berlangsung dalam bentuk penyampaian pesan dan menciptakan public opinion (2;) Membangun hubungan yang positif dan baik dengan pihak publik sebagai target sasaran yaitu publik internal dan eksternal. Khususnya menciptakan saling mempercayai (mutually understanding) dan saling memperoleh manfaat bersama (mutual symbiosis) antara lembaga/organisasi perusahaan dan publiknya (3;) Peranan back up management dan sebelumnya dijelaskan bahwa fungsi public relation melekat pada fungsi manajemen, berarti ia tidak dapat dipisahkan dari manajemen. Fungsi manajemen dalam konsep public relations bertujuan untuk menciptakan dan mengembangkan persepsi terbaik bagi suatu lembaga, organisasi, perusahaan, atau produknya terhadap segmen masyarakat, yang kegiatannya langsung atau tidak langsung mempunyai dampak bagi masa depan organisasi, lembaga, perusahaan atau produknya (4;) Menciptakan citra perusahaan atau lembaga (corporate image) yang merupakan tujuan akhir dari suatu aktivitas program PR. Peranan public relations mencakup bidang yang luas menyangkut hubungan dengan berbagai pihak dan tidak hanya sekedar berbentuk relations arti sempit, tetapi PR berperan dalam bagaimana meningkatkan 
kesadaran, pengertian dan pemahaman tentang aktivitas perusahaan dan lembaga, termasuk membentuk sikap yang menyenangkan (favoritable), itikad baik (good will), toleransi (tolerance), saling pengertian (mutual confidence), saling menghargai (mutual appreciation), dan pada akhirnya akan menciptakan citra baik (good image) (dalam Ruslan, 2013).

Praktik Public Relations erat kaitannya dengan media yang kemungkinan tidak akan berubah dalam waktu dekat, dan demi kepentingan perusahaan dan orang-orang, alangkah baiknya mengambil tindakan yang juga meningkatkan etika media relation. Bagi sebagian besar orang yang memiliki pengalaman dan berurusan dengan media, mengetahui bahwa media percaya mereka memiliki hak tertentu yang tidak dapat dicabut untuk mengakses informasi. Dan beberapa perilaku wartawan terkadang berkontribusi pada ketidakpercayaan dalam hubungan antara PR dan media.

Hubungan perusahaan dengan media perlu dijaga dengan mengedepankan kejujuran (honesty) dan ketetapan (accuracy) dalam menentukan informasi mana yang akan diungkapkan penuh dan mana yang tidak perlu diketahui oleh media (Parsons, 2016). Informasi yang disampaikan juga harus jelas dan akurat, sehingga tidak mengakibatkan orang tersesat atau tertipu. Informasi yang mengandung unsur tersebut dianggap bahwa Public Relations tidak jujur dengan informasi dan dapat mempengaruhi reputasi perusahaan itu sendiri.

Perlu sikap bijaksana (judiciousness) dalam menentukan kapan dan bagaimana Public Relations menggunakan media. Seorang Public Relations profesional perlu menyadari untuk menghindari penyumbatan saluran komunikasi publik dengan berita-berita semu atau beritaberita yang tidak benar. Melakukan tersebut memiliki efek berbahaya pada publik serta pada elemen kepercayaan dalam hubungan antar Public Relations dan media. Menanggapi media (responsiveness) juga merupakan salah satu aspek penting hubungan yaitu kepercayaan. Menerima panggilan media dan membalas panggilan media akan tampak seperti pendekatan strategis yang baik dalam membangun hubungan, tetapi memiliki dampak besar pada kepercayaan tersebut. Pilar terakhir adalah bertindak secara profesional dan menghargai (respect) setiap saat bahkan disaat sedang menghadapi kekasaran atau yang lebih buruk. Memperlakukan orang lain dengan hormat adalah langkah pertama menuju interaksi yang sangat bermoral. 
Pada intinya, kurangnya kepercayaan pada hubungan antara profesi Public Relations dan media pada dasarnya berhubungan dengan etika. Tindakan yang berkontribusi terhadap ketidakpercayaan selalu dipertanyakan secara etis. Sehingga, etika, memiliki aspek penting, peran penting, dan berpotensi tinggi untuk dimainkan dalam masyarakat. Berkaitan dengan media, dalam praktiknya, Public Relations memiliki pedoman perilaku profesional (Parsons, 2016) yang akan selalu menghindari beberapa perilaku berikut yang berhubungan media yaitu, menutup-nutupi kebenaran dengan apa pun alasannya, menyampaikan informasi dan berita yang tidak didasari pada fakta nyata, aktual, dan benar, mengambil bagian dalam usaha yang tidak etis dan tidak jujur yang dapat merusak martabat dan kehormatannya, menggunakan segala macam cara dan teknik yang tidak disadari dan tidak terkontrol sehingga tindakan individu tersebut sudah tidak lagi didasarkan pada keinginan pribadi yang bebas.

Dengan Public Relations patuh pada poin-poin diatas dan fokus pada menciptakan pola komunikasi serta saluran komunikasi dapat menjadi salah satu hal yang dapat berdampak pada peningkatan kepercayaan masyarakat. Public Relations yang secara praktik ditunjuk dalam mengeluarkan pernyataan atau press conference untuk menyampaikan pesan pesan dan informasi kepada publiknya, sesuai dengan acuan Kode Etik Profesional Humas, ada beberapa hal yang harus dilakukan yaitu, (1;) Public Relations harus mengacu pada pernyataan-pernyataan yang bernada positif dengan menghindari informasi negatif dan yang menarik perhatian publik (avoid negative news and withdrawal publication). Artinya, informasi-informasi yang sifatnya negatif dan yang tidak menguntungkan tidak disampaikan (2;) Public Relations menghindari pernyataan yang dapat menimbulkan salah pengertian, konotatif, kontroversial, dan polemik dengan pihak lainnya (3;) Begitu juga untuk pihak yang ditunjuk sebagai juru bicara perusahaan (spokesperson) untuk mengurangi kemungkinan pernyataan yang bertentangan yang dirilis ke media (Fearn-Banks, 2016), dapat memberikan pernyataan atau publikasi yang sifatnya positif dan menguntungkan bagi perusahaan yang diwakilinya.

Umumnya, ketika berita negatif sudah muncul di media massa yang sifatnya memojokan, merugikan, nama baik, dan reputasi narasumber atau organisasi dan lembaga, maka yang dianggap bersalah adalah pihak pers. Pada kasus maskapai LionAir tentang permasalahan ketentuan kapasitas bagasi dan di lapangan penumpang sebagai korban mencoba menjelaskan kepada media kronologi permasalahan yang muncul hingga disertakan bukti 
video disaat perdebatan petugas LionAir dengan penumpang. Penjelasan yang diberikan oleh penumpang itu disanggah oleh Danang Mandala Prihantoro sebagai Corporate Communications Strategic of LionAir, Danang menjelaskan segala ketentuan dan aturan kapasitas bagasi barang dan kabin, bahkan Danang menyangkal bawahannya mengatakan bahwa anak ibu harus membawa barangnya sendiri padahal anak tersebut berusia 3,5 tahun. Pihak LionAir dalam menyelesaikan kasus tersebut justru menambah polemic dan menimbulkan permasalahan baru yang dapat mengancam citra perusahaan. Lebih lanjut, atas pernyataan yang diberikan LionAir yang justru terkesan tidak bertanggung jawab dan tidak memberikan solusi dan toleransi dapat menurunkan tingkat kepercayaan publik.

Tindakan Danang setelah menjelaskan ketentuan kapasitas bagasi, tidak mengakhiri dengan permintaan maaf atas sikap bawahannya kepada penumpang, yang ia lakukan adalah klarifikasi dari maksud yang dilakukan oleh bawahannya. Berhubungan dengan salah satu strategi komunikasi dalam mengembalikan reputasi perusahaan adalah dengan melakukan permintaan maaf kepada korban serta publik. Setidaknya, publik akan berubah persepsi walaupun efek dari pernyataan Danang tersebut belum tentu hilang.

Untuk menanggapi sebuah keluhan customer bahwa masalah tersebut sudah tersebar di media sosial, dapat digunakan jawaban atau pernyataan yang rasional, yang tidak menyinggung dan bertanggung jawab. Juru bicara (spokesperson) sebagai seseorang yang paham komunikasi dan sebagai pihak yang melakukan praktik penyampaian informasi kepada publik, pesan-pesan sebelum sampai ke publik sebaiknya dikemas dan dirancang dengan baik sehingga pesan yang ingin disampaikan komunikator dapat diterima komunikan sesuai dengan maksud serta tujuannya.

\section{SIMPULAN}

Dalam kehidupan dimana pun kita berada Dibutuhkan etika sebagai pedoman bagaimana manusia akan bertindak secara etis dan baik dalam pengambilan keputusan sesuai dengan pedoman moral yang berlaku pada lingkungan individu berada. Etika Public Relations menjadi pedoman para profesional Public Relations dalam bertindak, bahan pertimbangan, dan membuat keputusan. Adanya Etika Public Relations membantu para profesional untuk tetap bertindak sesuai dengan kepentingan perusahaan ia berada. Terlebih, Public Relations yang melaksanakan praktik menyampaikan informasi kepada publik melalui media sebagai 
perwakilan perusahaan, tentunya setiap kata-kata, ekspresi, dan sikap harus dilakukan dan dipertimbangkan dengan hati-hati karena dalam pekerjaannya seorang Public Relations menjadi ujung tombak menjaga citra baik perusahaan. Pernyataan Public Relations setidaknya menghindari terjadinya kesalahpahaman dan kata-kata yang dapat menimbulkan polemik baik untuk perusahaan maupun pihak lain. Public Relations memiliki peran yang dapat membantu perusahaan ketika mengalami krisis yang harapannya dapat memperbaiki citra perusahaan dan mengubah persepsi publik terhadap perusahaan tersebut. 


\section{DAFTAR PUSTAKA}

Bowen, S. A. J. J. O. P. R. R. (2005). A practical model for ethical decision making in issues management and public relations. 17(3), 191-216. doi: 10.1207/s1532754xjprr1703 1

Fearn-Banks, K. (2016). Crisis communications: A casebook approach: Routledge.

Lieber, P. S. J. J. o. M. M. E. (2005). Ethical considerations of public relations practitioners: An empirical analysis of the TARES test. 20(4), 288-304.

Parsons, P. J. (2016). Ethics in public relations: A guide to best practice: Kogan Page Publishers. PERHUMAS (Perhimpunan Hubungan Masyarakat Indonesia). Kode Etik Perhumas. (2020, April 8). Diakses dari https://www.perhumas.or.id/kode-etik-perhumas/

Arnani, M. (2019, Mei 3). Kompas.com. Retrieved from Kompas.com: https://regional.kompas.com/read/2019/05/03/10125431/viral-pilot-pukul-pegawai-hoteldi-surabaya-lion-air-beri-sanksi

Creswell, J. W. (1994). Research Design: qualitative, quantitative, and mixed method approaches. SAGE Publications, 4.

Kami, I. M., \& Dinillah, M. (2019, April 29). News.detik.com. Retrieved from News.detik.com: https://news.detik.com/berita/d-4529827/penumpang-vs-lion-air-soal-balita-bawabagasi

Ramdhani, D. (2019, april 29). Kompas.com. Retrieved from Kompas.com: https://regional.kompas.com/read/2019/04/29/15395371/6-penumpang-ditinggalpesawat-karena-diduga-kelebihan-bagasi-ini-penjelasan

Ruslan, R. (2013). Kiat dan Strategi Kampanye Public Relation. jakarta: Rajawali Pres.

Sugiyono. (2018). Metode Penelitian Kualitatif. Bandung: CV. Alfabeta.

Tanjung, C. A. (2019, Februari 15). Detiknews.com. Retrieved from Detiknews.com: https://news.detik.com/berita/d-4430295/kalajengking-mirip-laba-laba-di-pesawatlion-air-dari-mana-asalnya 